\title{
学術文献における引用分類の観点
}

\section{Study of Citation Classification Scheme on Academic Articles}

\author{
柴田大輔 ${ }^{*}$, 芳鐘冬樹 ${ }^{1}$ \\ Daisuke SHIBATA $^{1 *}$, Fuyuki YOSHIKANE ${ }^{1}$
}

\section{1 筑波大学大学院 図書館情報メディア研究科}

Graduate School of Library Information and Media Studies, University of Tsukuba

干 305-8550 茨城県つくば市春日 1-2

E-mail: daisuke.shibata@gmail.com, fuyuki@slis.tsukuba.ac.jp

*連絡先著者 Corresponding Author

本研究では, 研究評価指標や情報検索技術の改善に利用される学術論文の引用情報について 概念的な整理を試みた. 第一段階しして, 引用をタイプ別に分類した様々な先行研究から分類スキ 一マを抽出し，その観点を(1)意義的観点，(2)評価的観点，(3)機能的観点，(4)形態的観点, (5)位置 的観点, (6)社会的観点の6観点に分けて再定義した. 第二段階として, 第一段階で得られた各観点 について尺度水準, 推奨される分類スキーマ, 活用時の注意点を考察した. 従来複合的な観点から 構築されていた区分を分離し, 異なる観点として位置づけられてきた区分を統合することで, 引用分 類についての基礎的なスキーマを作成できた.

In this research, we attempt to classify and arraign citations in academic articles. They were variable classification type by each previous research, and were not organized has been a problem. First stage, we reorganized their by perspective, (1) significance type ,(2)evaluative type, (3)functional type, (4)morphologic type, (5)location type, (6)sociological type. Second stage, we discussed scaling level, recommended classification scheme, and point to be noted, for perspectives obtained in the first stage. A division that has been built from the complex perspective to separate, by integrating the division, which has been positioned as a different perspective, we create a basic scheme for the citation classification.

キーワード：引用分析, 引用の分類, 計量書誌学, 研究評価

Citation Analysis, Citation Classification, Bibliometrics, Research Evaluation 


\section{1 はじめに}

本研究では, 学術文献の引用を対象に, それらを実際に客観的に分類することが 可能なスキーマの基盤構築を目指して, 分類観点の設定を行う。本研究では，引 用のタイプを観点ごとに系統的に整理し た枠組みを,引用の分類スキーマと呼ぶ. 分類スキーマにおいて，各観点は区分と して表現され，個々の引用のタイプは区 分肢として定義・列挙される.

学術的なコミュニティにおいて文献を 執筆する際, 他者の文献や研究を活用し たことを明示するため参照文献を記述す る.このようにして発生する引用した／ されたという関係は，定量的かつ客観的 なデータとして扱えることから学術的な コミュニティの動向調查や雑誌のインパ クトを測定するためなどに用いられる. 近年では, 学術雑誌出版社の PLOS が引 用元文献（引用をした文献）と被引用文 献（引用された文献）間の引用関係をグ ルーピングすることにより論文同士の関 係性を詳細に示すことが可能なデータ心゙ 一スを開発中 ${ }^{1}$ であったり, 効率的な電子 出版を目指す Semantic Publishing の動き が起きつつある中で引用関係を明示した オントロジー, CiTO（The Citation Typing Ontology）が開発される[1]など，引用を タイプ別に分けることによって情報検索 方面への応用に役立つ可能性も見えてい る。しかし，このような引用をタイプ別 に分ける行為については多くの研究があ るにもかかわらず，その目的，手法，分

${ }^{1} \mathrm{http} / / /$ www.plos.org/rich-citations-open-data -about-the-network-of-research/
類スキーマ作成の観点や尺度，判断基準 などが極めて多様なまま形成されており， 引用という行為を統合的・俯瞰的に捉え ることができない状態にある.Small[2] によって, “分類スキーマの作成において 累積的な努力がなくそれぞれの研究がユ ニークな存在になってしまっている”と いう指摘があるように，分類スキーマの 構造や用いられる区分についての検証を 俯瞰的に行った研究が少なく，実際に引 用を分類して研究へ応用するためには分 類やリスト化が行われる際の観点を整理 することが必要であると言える.

引用の分類スキーマを活用するために は，主に 2 点の課題がある. 1 点目は, 分類スキーマにおける区分および区分肢 に関する課題であり，2 点目は，分類ス キーマそのものでなく，分類作業に関す る課題である．社会科学とその関連分野 で実証的に引用分類スキーマを用いた Peritz[3]は, 複数の米国科学雑誌から論文 および引用を抽出し, 各区分肢の構成比 率を調査した. 8 区分肢で構成された分 類スキーマは，定義の段階で「歴史的」 という区分肢がしばしば「ステージのセ ット」という区分肢と不可分になりがち であることに触れられていた。これは分 類スキーマにおける個々の区分肢の定義 が相互排他的ではないことを表しており， 「ステージのセット」という区分肢の割 合が最多（33.4-49.5\%） となる傾向が調 査対象全誌に共通し「歴史的」という区 分肢の割合が非常に少ない（0.3-4.0\%) 結果であったことを示されても，その結 果を信じてよいか疑問が生じる。一方, 分類作業とは分類スキーマに個々の引用 
をあてはめる作業，または，個々の引用 にラベルを付与する作業を指す。分類作 業の面からは，現実的な判断可能性に関 する問題がある。例えば，引用元文献の 文章を読み，ある引用が分類スキーマの ある区分肢に該当するか判断する際，記 述部分が極端に短く判断材料が含まれて いなければ判定は極めて難しくなる。こ れでは，分類スキーマにおける各区分肢 の定義が明確であっても分類ができない ことになる。これら 2 点の課題は分類に ついて検討する際, 本質的に避けられず, 完全な解決は難しい。しかし，今まで先 行研究で用いられてきた分類スキーマの 区分や区分肢を，引用という現象の側面 から分野や用途を限定せず俯瞰的に統合 整理することで，これまで網羅できなか った区分肢の補完や，区分肢の定義を議 論しやすくするための基盤を作ることは 可能である.

そこで, 本研究では, 先行研究が提案・ 利用している様々な引用分類について紹 介した後，それらに含まれている要素を 分類の観点から俯瞰的に整理・再定義し, 各観点について客観性・実用性のある区 分や判断基準を検討する.

\section{2 先行研究}

\section{1 代表的な引用分類研究とスキーマ}

引用分類に関連する研究は 1960 年代 から行われている. Garfild[4]は，「機械的 に引用索引を作るためにはそもそも文献 の執筆者が適切な引用を明示的に行って いなければ処理できない」と考え，引用 が行われる理由を 15 種類列挙した (表 1 ). 同時代に Liepetz[5]も引用索引の改善を
目的として引用理由を挙げている. The Physical Review 誌, Soviet Physics 誌 (JETP) から 60 文献 750 引用を抽出し て考察し， 4 グループ 29 区分肢の引用理 由を挙げた(表 2)。ただし，これらの論文 は考えられる理由を列挙しており，統計 的・実証的に分類することを目的とした わけではない。

当初は引用が行われる理由などの行動 学的な側面に焦点があてられ理由のリス トアップが中心だったが，次第に作成し た引用分類スキーマを用いて実際の文献 で行われている引用を分類する実証的な 研究が始まり，どのようなタイプの引用 が多いのか明らかにされた。

表 1 Garfield[4]が列挙した引用理由

\begin{tabular}{|ll|}
\hline 1. & 先行研究者への献辞 \\
2. & 関連業績に対する敬意 (同輩への敬意) \\
3. & 方法論や装置等の確認 \\
4. & 背景説明の提示 \\
5. & 著者自身の研究の修正 \\
6. & 他の研究者の研究の修正 \\
7. & 先行研究の批判 \\
8. & 主張の立証 \\
9. & 引き続く研究のアラート \\
10. & あまり知られていない, 引用もされて \\
& いない研究の紹介 \\
11. & データや一群の事実の認証（物理定数 \\
& など） \\
12. & アイディアや概念が議論された当初の \\
& 文献を確認 \\
13. & もともとの概念や用語が著された文献 \\
& の確認 \\
14. 他人の著作や考えに対する否認 \\
15. 他人の先行する主張に反論
\end{tabular}

1. 先行研究者への献辞

2. 関連業績に対する敬意 (同輩への敬意)

3. 方法論や装置等の確認

4. 背景説明の提示

5. 著者自身の研究の修正

6. 他の研究者の研究の修正

7. 先行研究の批判

8. 主張の立証

9. 引き続く研究のアラート

10. あまり知られていない，引用もされて 䋨介

データや一群の事実の認証（物理定数 アイディアや概念が議論された当初の

15. 他人の先行寸る主張に反論 
表 2 Liepetz[5]における引用分類

\begin{tabular}{|l|}
\hline グループ 1: オリジナルな科学的貢献または引用 \\
文献の意図 \\
観測された現象の記述, データの変換, \\
説明, 仮説や理論, 理論の計算, 予測, \\
定義, 実験技術の宣言 \\
\hline グループ $2:$ オリジナルな科学的貢献以外の引用 \\
文献の貢献 \\
レビュー論文, 書誌, データの累積 \\
\hline グループ 3: 引用文献が被引用文献との違いや継 \\
続関係を示すため \\
共通の著者, 同じテキスト, アブストラクトや \\
要約, エラー訂正, 継続, 先駆者, 包括 \\
\hline グループ4: 引用文献におけ被引用文献の科学 \\
的貢献の性質 \\
注釈されただけ, 区別された, レビューまたは \\
比較された, 忘用された, 改善・修正された, \\
置き換えられた, 精度を変えた, 適用される範 \\
囲を変えた, 疑問視した, 肯定した, 反対した
\end{tabular}

Murugesan と Moravcsik[6]は物理学の 論文における引用を分類するため, 二項 対立的にとらえられる観点を持った分類 スキーマを作成し，実際の文献における 引用を対象として分類作業を行った。 1968 年から 1972 年の間に Physical Review 誌に掲載された 30 文献 575 引用 を対象とし，各引用が各観点のどちらに 当てはまるかを調査し集計した（表 3）. 結果からは，確認的な引用が否定的な引 用に比べ多いことが明らかとなり，どち らでもない・どちらにも該当するような 引用が多くないことから一定の評価を得 て, 多くの引用分類スキーマで同様の観 点が組み込まれた $7 ， 8 ， 9 ， 10]$.

Vinkler[11]は，引用を行う動機には， 他の研究との関係を持たせる「専門的な 動機」と科学コミュニティにおける社会 的な関係を構築する「接続的な動機」の 2 種類あると考え，それぞれ複数の選択 肢を挙げて化学分野の研究者 20 人を対
象にアンケートを行った. それら 20 人が 執筆した 20 文献 484 引用についてどの選 択肢が該当するか複数回答可として調査 した。調查結果からは，81\%の引用は専 門的動機のみであり，17\%の引用は専門 的動機・接続的動機の両方あり, $2 \%$ の引 用が接続的動機のみであることがわかっ た．つまり，大多数の引用は「論文の序 論の完成度を高めるため」や「被引用文 献の理論や手法の一部を参考にした」

表 3 Moravcsik と Murugesan[6]の分類スキー

\begin{tabular}{|c|c|c|c|}
\hline 観点 & \multicolumn{3}{|c|}{ 比率 } \\
\hline \multirow{2}{*}{$\begin{array}{l}\text { 概念的（概念や } \\
\text { 理論の引用） } \\
\text { か, 操作的（ツ } \\
\text { 一ルや物理的 } \\
\text { 技術の用）か }\end{array}$} & 概念的 & 操作的 & $\begin{array}{l}\text { どちらで } \\
\text { もない }\end{array}$ \\
\hline & $53 \%$ & $43 \%$ & $7 \%$ \\
\hline \multirow{2}{*}{$\begin{array}{l}\text { 有機的（引用文 } \\
\text { 献の理解に必 } \\
\text { 要な引用）か, } \\
\text { おざなり (謝意 } \\
\text { を示すためたの } \\
\text { 引用) か }\end{array}$} & 有機的 & おざなり & $\begin{array}{c}\text { どちらで } \\
\text { もない }\end{array}$ \\
\hline & $60 \%$ & $41 \%$ & $1 \%$ \\
\hline \multirow{2}{*}{$\begin{array}{l}\text { 進化的（引用文 } \\
\text { 献が被引用文 } \\
\text { 献を基礎にし } \\
\text { て積み上げて } \\
\text { いる）か, 並列 } \\
\text { 的（引用文献が } \\
\text { 被引用文献の } \\
\text { 代わりになる） } \\
\text { か }\end{array}$} & 進化的 & 並列的 & $\begin{array}{l}\text { ぞちらで } \\
\text { もない }\end{array}$ \\
\hline & $59 \%$ & $40 \%$ & $2 \%$ \\
\hline \multirow{2}{*}{$\begin{array}{l}\text { 確認的（被引用 } \\
\text { 文献が正しい } \\
\text { と確認された） } \\
\text { か, 否定的（被 } \\
\text { 引用文献の正 } \\
\text { しさに異議を } \\
\text { 唱える）か }\end{array}$} & 確認的 & 否定的 & $\begin{array}{c}\text { どちらで } \\
\text { もない }\end{array}$ \\
\hline & $87 \%$ & $14 \%$ & $5 \%$ \\
\hline
\end{tabular}

$\mathrm{N}=575 \quad$ ※各観点における区分肢ごとの比 率を足しても 100\%にならないのは，どちら にも該当する引用が存在するため 
などの専門的動機により行われつつも， 一部の引用には「自己の文献を広めるた め」などの接続的動機も含まれていた. それまで行われていた引用分類に関する 研究では, 専門的動機により生起する引 用を中心に想定とされていたが，実際に は読者やコミュニティに所属する人間と つながることを目的に含んで引用するこ とが明らかになった。

Small[12]は Citation Cube とよぶモデル で引用行動について整理した。Citation Cube では，引用しているコミュニティに おける賛成の度合いを表す次元である “総意度”, 引用した文脈と被引用文献 との適合度を表す “固執度”, 自己引用 の度合いを表す “公平度”と名付けた $3 つ$ の次元を直交させることにより 8 区分で 引用を分ける.それぞれの次元には高低 が存在し, 総意度と固執度の 2 次元を交 差させた場合は表 4 のようになる. 表 4 に記載されていない公平度は, 上記 2 次 元から作られる 4 象限に対して自己引用 か否かという点で分割するための次元と なっている．この Citation Cube によるモ デルは引用という行為について 3 次元か ら判別できるが，あくまで引用行動につ いての概念的な整理方法であり実証的な 分類方法でないためか, 活用はされてい ない.

Harwood[13]は社会学分野および計算 機科学分野の研究者それぞれ 6 人ずつを 対象に，引用の機能を調査した。従来の 研究とは異なり, あらかじめ引用理由や 分類スキーマを作成してその比率などを 調査する手法ではなく, インタビューに 基づく談話分析を行い，その結果として 引用のタイプを 11 種類ほじ見出した（表
5).さらに，インタビュー結果における 各区分肢の出現頻度を調査したところ， 「立場」「補足」「信頼」といった機能に ついての言及は社会学分野と計算機科学 分野共通の傾向として見られたのに対し, 社会学者では「約束」が, 計算機科学で は「道標」がそれぞれ多く見られた。こ のことから，分野によって引用を行う目 的が慣習的に異なることも示唆された.

表 4 Small[12]による Citation Cube

\begin{tabular}{|c|c|c|c|}
\hline & \multicolumn{2}{|c|}{ 総意度 } \\
\hline & & 低 & 高 \\
\hline \multirow{2}{*}{ 固執度 } & 低 & $\begin{array}{l}\text { 【構成的】 } \\
\text { 誤帰属, 再解釈, } \\
\text { 特異な否定, 革 } \\
\text { 命的 }\end{array}$ & $\begin{array}{l}\text { 【構成的】 } \\
\text { 慣習的否定, 共通 } \\
\text { の誤帰属, 因習的 } \\
\text { な転換, 結合によ } \\
\text { る消滅 }\end{array}$ \\
\hline & 高 & $\begin{array}{l}\text { 【規範的】 } \\
\text { 本質的, 有機的, } \\
\text { 創造的なつが } \\
\text { り, 普通ではない } \\
\text { 引用 }\end{array}$ & $\begin{array}{l}\text { 【規範的】 } \\
\text { おごなり, 儀式的, } \\
\text { 共通の直引用, } \\
\text { 従来の解䣋, 模範 } \\
\text { 的 }\end{array}$ \\
\hline
\end{tabular}

\section{2 引用分類研究の整理}

引用を分類する研究には歴史と積み重 漦があり, すでに先行研究を整理した文 献が存在する。

Bornmann と Daniel[14]は，引用回数を 数えることの意義について考察するため, 1960 年代初頭から 2005 年中盤までに出 版された約 30 編の引用行動に関する研 究結果をまとめ, その過程で引用を分類 する実証的な研究について言及した。 そ の際，(1)文脈分析や内容分析，(2)引用行 動のトピックについての郵便調査や対面 インタビューといった調査手法ごとに整 理した。(1)は文献間の関係を発見するた めに用いられる。 その中でも文脈分析 
表 5 Harwood[13]による引用の理由

\begin{tabular}{|c|c|}
\hline 道標 & $\begin{array}{l}\text { 詳しくない読者への補助, 興味を } \\
\text { 引く } \\
\text { 議論の足跡を保持 } \\
\text { 場所の節約 }\end{array}$ \\
\hline 補助 & トピック, 手法, 主張の正当化 \\
\hline 信頼 & $\begin{array}{l}\text { 著者の債務 (著者のオリジナリテ } \\
\text { イへ敬意を払う) } \\
\text { 信頼と自己防衛 } \\
\text { 信頼と評価的形容詞 }\end{array}$ \\
\hline 立場 & $\begin{array}{l}\text { 立場の手本 } \\
\text { 立場や結果の詳細な説明 } \\
\text { 時間をかけた立場のトレース }\end{array}$ \\
\hline 約束 & $\begin{array}{l}\text { 称賛した後情報源の問題を識別 } \\
\text { 情報源の立場における矛盾の識別 }\end{array}$ \\
\hline 積み上げ & 自己引用による継続的な積み上げ \\
\hline 連結 & $\begin{array}{l}\text { 他の手法, 学派, 議論と抱きあわ } \\
\text { せる }\end{array}$ \\
\hline 報知 & $\begin{array}{l}\text { 自らの著作を読者へ知らせる } \\
\text { 他者の著作を知らせる }\end{array}$ \\
\hline 未来 & 著者が描く未来の地図 \\
\hline 能力 & $\begin{array}{l}\text { 文献の知識を示す } \\
\text { 今後の研究を実現する可能性を示 } \\
\text { す }\end{array}$ \\
\hline 話題性 & $\begin{array}{l}\text { 研究が新しい課題であることを示 } \\
\text { す }\end{array}$ \\
\hline
\end{tabular}

は引用元文献の引用周辺テキストに基づ いて分析を行う手法であり，内容分析は 引用元文献の意味内容から被引用文献を 特徴づける手法とした。作業者によって 判断が異なる場合もあり, 分野による引 用行動の差や文献タイプによる差が生じ る可能性もあり，全文を読んで判断でき るエキスパートが必要になることが弱点 でもある。ただし，研究対象の量を増や しやすく統計的な分析を行いやすい. 対 照的に(2)の手法は引用の動機や目的を 調査する研究であり, 研究者を対象に科 学行動学的な側面から行う分析手法であ る. 他者が推測するより引用の理由が正 確とも考えられるが，著者への質問は真 の理由を明らかにできないこともあり （正直に回答するとは限らない，著者本
人も理由を忘れてしまう，共著者が執筆 した部分である等)，全面的に正確である とは言えないとした. Bornmann と Daniel の論文は引用回数を数える意味について 迫るものではあるが，引用を分類する場 合に見られる観点やその性質について明 らかにするところまでは踏み込んでいな い.

Ying ら[15]は，従来の引用分析を超え た“内容に基づく引用分析(Content-based citation analysis: CCA)"を推進するため, (1)理論的基礎, (2)アプローチ, (3)アプリ ケーションの各段階から, 引用を分類す る研究について整理した。(1)理論的基礎 としては，(1)構造的な分析方法と (2)意味 的な分析方法の 2 つを挙げた。(1)は introduction, related works, methods, results, discussion, conclusions といったセクショ ン構造を活用する方法であり，(2)は引用 によって関係づけられる文献間の意味的 な分析を行う方法である. (2)アプローチ については，(1)手作業による内容分析と (2)自然言語処理による半自動的な分析が あるとし, 複数の研究 $[3,5,16,17,18$, 19，20，21]で用いられた分類スキーマの 区分肢について，Background information， Theoretical framework, Prior empirical/experimental evidence, Negative distinction, Methodology explanation $の 5$ 区 分にグループ化し直している．（3)アプ リケーション, 寸なわち研究の適用とし ては(1)引用動機の分類のため, (2)自動文 章要約のため, (3)検索のため, (4)引用の 推薦および予測, (5)ナレッジグラフマイ ニングの 5 つを挙げた. Ying らの研究で は引用分類研究が行われる背景やその方 向性について整理されたが，個々の研究 
で行われた分類スキーマの妥当性につい ては言及されておらず，区分肢の整理が 不十分であると言える. そのため引用分 類研究を概観することはできるものの, 引用分類自体を概観できるとは言えない.

\section{3 引用分類スキーマの統合}

先行研究で用いられている区分肢を統 合して分類スキーマを作成する研究も存 在する.

Brooks はそれまでの研究で用いられて いる区分肢のうちいくつかを用いて引用 動機の分類スキーマを作成し [7]，それ らの関連性を調査した[22]. 様々な分野 から選定した 20 人の著者に対し, 各自の 著作内の引用について，あらかじめ用意 した 7 区分肢のうちいずれに当てはまる か回答を求めた７ 区分肢からなるスキ ーマは, (1)Line と Sandison[23]が表現し た”新しさ”, (2)Garfield[4]が表現した”ネ ガティブな信用”， (3)Murugesan と Moravcsik [6]で用いられた”操作的な情 報”，(4)Gilbert[24]が引用とは読者を説得 するために行っていると提唱した”説得 性”, (5)Garfield[4]が定義した”ポジティブ な信用”, 同じく(6)Garfield[4]が定義した” 読者へのアラート”, (7) Bavelas[25]が研 究分野で慣習的に行われる不特定かつ曖 昧な動機で行われる引用を称した”社会 的総意”である.1つの引用に対し複数の 区分肢を付与することも可能として分析 した結果， $29.3 \%$ の引用は 1 つの理由, $70.7 \%$ は複数の理由が付与された。 また， これらの区分肢に対して主成分分析を行 った結果，(1) (4) (5) (7)からなる”新し く・重要で・必要と判断される引用のグ ループッと,(2)だけのネガティブな引用の
グループ, (3) (6)からなり読者への背景説 明の意味を込めた”サービス的な動機の グループッの 3 グループに分けられると した。しかし，研究対象とした分野が多 岐にわたりサンプル数があまり多くない. また，大多数の引用に複数のカテゴリが 付与されることから，分類スキーマとし ては整理されていないと言える.

Garzone と Mercer[8]は Citation Index に 引用の機能的な区分を自動的に付与する ための手法を提案した。分類スキーマは 複数の研究 $[3,6,20,26,27,28,29$, 30]に基づいて Garzone[31]が作成した 10 カテゴリ 35 区分肢で構成されたスキー マを用い, Garzone が物理学 8 論文と生化 学 6 論文を分析して開発した構文解析ル ールに基づいて自動分類を行った. 10 カ テゴリとは，(1)否定的タイプ，(2)肯定的 タイプ，(3)仮説的タイプ，(4)暫定的タイ プ，(5)手法的タイプ，(6)解釈的 /開発的 タイプ, (7)将来的研究タイプ, (8)概念的 物質使用タイプ，(9)比較タイプ，(10)読 者へのアラートである. 物理学 3 論文, 生化学 3 論文を実験対象とし，人手によ って付与されたカテゴリと自動分類によ って付与されたカテゴリを比較したとこ ろ, 物理学は $41 \%$ が正しく, $21 \%$ が部分 的に正しく，38\%が間違いであり，生化 学は $61 \%$ が正しく, $12 \%$ が部分的に正し く, 27\%が間違いであるという結果にな った。この結果は引用の方法や記述形式 が分野によって異なる可能性とともに機 械的な判定の難しさを示している. また, 例えば重複するとは考えにくい「否定的 タイプ」と「肯定的タイプ」が並列的に 扱われているなど， Moravcsik と Murugesan[6]の研究で用いられた「軸」 
といら概念は見られない.

以上のように引用を分類する研究にお いては，引用分類研究の手法と引用分類 スキーマの区分肢についてのグループ化 がなされているものの，分類スキーマの 区分肢を観点から整理し直し，妥当性を 考察した研究は見当たらない，そこで本 研究では，引用を分類する際に使用され る観点を整理・再定義したのち、個々の 観点の特性について述べる.

\section{3 観点の再定義}

本研究の目的は引用を分類する観点につ いて俯瞰的に整理・再定義することにある. そのため研究目的（研究者の引用行動を明 らかにする，評価指標への応用，引用索引 や検索精度の改善等), 調査手法 (内容分析, アンケート等）および分析対象分野を限定 せずに，学術文献の引用をタイプ別に分け た先行研究・先行事例を収集し調査対象と した（付表1）。これらで用いられた分類ス キーマ中の区分肢や，質問紙中の質問項目 等について，同じ観点と考えるのが妥当な ものを同一観点として集約した，以下では その結果として得られた観点について区分 肢等の実例を記載し，観点の範囲を再定義 している.引用を分類する場合には「時間」 や「分野」により分けた分析が行われるこ とがあるが，それらは周知の事実であり再 整理の必要がないため本研究の範囲には含 めなかった。

\section{1 意義的観点}

引用にどれほどの意味があるか（有意 性）から分類する観点を意義的観点とよ ぶ.有意性は「周辺的 - 中程度 - 重要
不可欠」[10]といった段階的な区分 や「有機的 vs おざなり」[6]や「中心的 vs 周辺的」[21]といった 2 項対立的な区分 肢だけでなく，「被引用文献が中心的な 扱いをされている」[16], 「レファレンス を増やす必要がある（実際は必要ない）」 [11]などのように質問項目が設定される こともある。それぞれ表現に異なりはあ るものの引用の必要性・有意性という概 念で定義することができる．引用元文献 により決定される被引用文献を引用する 意義により重みをつけることで，単純な 被引用数よりも改善した研究評価方法が 可能となる.

\section{2 評価的観点}

被引用文献に対する引用元文献の評価 から分類する観点を評価的観点とよぶ. 著者が被引用文献へ行う評価には賛成・ 肯定といった「ポジティブな評価」や否 定・批判といった「ネガティブな評価」 のように「賛否」という分け方も存在す る.「確認的 vs 否定的」[6]という対立的 な見方だけでなく，「弱点を指摘した引 用，アプローチの取り方や問題の所在を 肯定的にとらえた引用，中立的な記述」 [32]などのように肯定や否定の対象とセ ットで区分肢として扱われる場合や， 「部分否定，完全否定」[16]のように強 弱が意識される場合もある。被引用数に よって被引用文献を評価する際にネガテ イブな引用を除外する措置を行うことで, 被引用数による単純なインパクトではな く著者の評価的スタンスを含んだ評価指 標を作成することが可能になる．引用元 文献は被引用文献に対して，「研究動機 を語る上で必要ではあるが，賛成はして 
いない」ということもあり，必ずしも有 意性と評価は一致しない. そのため主な 用途として研究評価指標の改善という点 で類似しているものの概念的な分類の観 点としては分けて取り扱うべきであると 言える。

\section{3 機能的観点}

引用の機能や役割から分類する観点を 機能的観点と呼ぶ. 引用行動や文章の意 図を調査する場合, この観点から分類さ れることが多い.ある被引用文献が引用 元文献中で引用される場合，その目的は 一様ではない，同一の文献であっても研 究方法を参照するために引用される場合 もあれば，自らの研究結果を考察する際 の比較対照として引用される場合もある. そのため著者が引用した用途や目的の情 報を引用索引に付加できれば，引用した /されたという関係以上の情報を引用索 引の利用者へ提供できることになる.

機能的な観点に該当する区分肢は先行 研究でも様々な表現で用いられている. 被引用文献の理論や概念を引用したか, あるいは実験手法や操作方法を引用した か[6，11，19，22]という捉え方は，「引用 対象の具体性」から判断した分類となる.

先行研究からの継続性から分類するこ とも可能である.「継続, 包括, 改善, 修 正された, 応用された, 置き換えられた, 精度を変えた, 適用される範囲を変えた」 [5]などの区分肢や「被引用情報源がリサ 一チクエスチョンの出発点になる, 引用 文献の結果で被引用情報源のデータの新 解釈や説明を追加」 [18]という区分肢は 先行研究の継承や適用範囲拡大といった 積み上げ方を表しているともいえる。「未
来への言及」 $[4,13]$ も将来的な発展・継 続の可能性を示寸区分と捉えることがで きるため機能的観点における継続性を表 す区分として扱うことができる．ライデ ン大学の Centre for Science and Technology Studies (CWTS)が開発してい

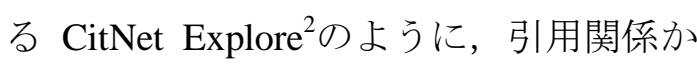
ら研究者の系譜をわかりやすく整理する ことによりコミュニティの全体像をつか む際により精度が上げる効果が期待でき 万.

「具体性」や「継続性」のように一つ の軸を形成しているわけではないが，機 能面から引用を分類する場合には，被引 用文献によって「背景説明」を行うため [4，33，34]，自研究において検証をおこ なう「仮説」として位置づけるため $[3,5$, 8] , 先行研究における検証方法との同一 性を宣言したり定義を参照することによ り研究トピック・採用手法・自著の主張 の説得性・正当性を強化するため $[4,5$, $8,13,18,32,33,34,35,36,37]$, 先行研究の方法や目的, 結論などを対 比・比較するため $[18,32,33]$, 先行研 究や関連研究の認知度を上げ被引用文献 を読者へ広めるため $[4,7,11]$ という目的 も機能的な観点に含まれる区分である.

\section{4 形態的観点}

被引用対象の形態的な側面から分類す る観点を形態的観点と呼ぶ. 被引用対象 はデータの場合もあるため必ずしも文献 とはならないが，例えばレターなどの速 報性が高い文献がよく引用される分野を 見出し分野内の引用行動を把握すること

2 http://www. citnetexplorer. nl/Home 
で，より適切な図書館のコレクション管 理を行うことが可能になる，原著論文， レビュー論文などの文献タイプから分類 される[5]が，被引用対象の入手先といっ た所在情報による分類もコレクション管 理には役立つ観点となる。近年では学術 情報の電子化によってトムソン・ロイタ 一社がデータ引用に基づくツールである Data Citation Index を公開するなど被引用 対象の捉え方は旧来の「文献タイプ」と いう分類だけではおさまらないと言える. そのため, 従来の引用分類では行われて こなかった「被引用データ」も含めるべ きである。

$$
\text { ジャーナルインパクトファクターを算 }
$$

出する場合は原著論文とレビュー論文の みが集計対象となるなど，文献タイプの 区分は研究評価指標へ応用する際にも不 可欠な区分となっているため，評価的観 点を生かすためにも有用な観点となる.

\section{5 位置的観点}

引用が生起している箇所の位置に基づ いて分類する観点を位置的観点と呼ぶ. 引 用分析を行う際には全ての引用を等しく 扱うのではなく文献のどこで引用された かを含めるべきであるとする考え方に対 応する観点である。学術的な文献を記述す る際には，「はじめに」や「方法」のよう に文の内容ごとに見出しが設けられ，文の 意味内容により章や節として区切られて いる．異なる章や節で行われる引用は，そ の理由や目的, 機能が異なると考えられた ために，分類することが提案された[38]. 機能的観点で分類する場合には本文の記 述内容を基に判断するが，位置的観点で分 類する場合はその必要がなく, 提唱された
当初は機能的観点の代替としての側面が 強かった. 3.2で示した機能的観点の中でも 「背景説明」などは論文のはじめの部分に 多く出現する可能性が高いなど，文章中の 出現位置から引用の機能を推測可能な場 合はある。しかしながらオープンなフルテ キストが使用しやすくなっていることか ら位置的観点で機能的観点を代用する必 要は少なくなり，明確に両者を区別するべ きであるとの立場から本研究では異なる 観点として扱う。

引用の位置は引用元文献の「構造的な 位置」から捉えられる．例えば情報行動 的な側面として機能的観点と組み合わせ て引用の分布を調べる場合には，「序論 方法 - 考察 - 結論」[38]や IMRaD 構造の ように本文中のセクションから分類する 場合や, 文単位 [39], 単語単位 [40], 文 字単位[10]で引用元文献の長さを表し引 用の出現位置を定義する場合がある。ま た，引用された位置の近さから被引用文 献同士の類似度評価に用いる場合は,

「章」単位に加え「節，段落，文，列挙 （列挙とは文末などで複数の引用を並べ る形を指す)」[41，42]単位で位置を捉え る場合もある。

\section{6 社会的観点}

著者が引用を行う社会的な背景に基づ いて分類する観点を社会的観点と呼ぶ. 科学社会学的, 行動科学的な側面から情 報行動や引用行動などの特徽を把握する 際に有用な観点である。ここで述べる社 会的とは，研究コミュニティとの関わり に起因する引用を指し，「コミュニティの 人的つながりによる引用，コミュニティ の慣習による引用」などがある. 
「コミュニティの人的つながりによる 引用」は「被引用文献の著者と専門的な つながりを作りたい・維持したい」[11] や「知人の論文であるため引用した」な ど，人的関係の構築や人的影響により発 生する引用を含む. 自己引用の場合も再 帰的ではあるが「過去の自己とのつなが りによる引用」と考えることもできるた め，人的つながりによる引用に含む. 自 己引用と他者引用を行った際の動機には 大きな差が見られない [35]ことから，評 価的観点では分けて考えるべきであるが， 社会的観点においては自己引用か他者引 用かといった違いはあまり重要ではない。

「コミュニティの慣習による引用」は 「政治的な圧力で引用しなければならな かった」 [35], 「研究トピックの先駆者・ 研究領域の権威者を引用寸る」 $[4,5,7$, 12，34]や「他の研究者が引用していたた め」[11]などコミュニティ内で何らかの妥 当性を持って行われた引用を指寸。

これらの社会的観点で捉えられる引用 は，著者が研究コミュニティの構成員と しての役割を踏まえて執筆を行うために 発生する。必ずしも被引用文献の評価を 行ってはいないため評価的観点からすれ ば「おざなり」とも見られ有用性は低く 扱われる場合があるものの，引用関係か らコミュニティの全体像や傾向を把握す るためには十分に活用できる情報である.

以上のように整理した結果を表 6 にま とめた。

\section{4 各観点の特性}

4章では，3章で設定した各観点に該当す る区分について, 尺度水準, 推奨される分
表 6 引用分類の観点と定義

\begin{tabular}{|c|l|}
\hline \multicolumn{1}{|c|}{ 観点 } & \multicolumn{1}{|c|}{ 観点の定義 } \\
\hline (1)意義的観点 & $\begin{array}{l}\text { 行われた引用の有意性から } \\
\text { 分類する観点 }\end{array}$ \\
\hline (2)評価的観点 & $\begin{array}{l}\text { 被引用文献に対する引献の評価により分類する } \\
\text { 観点 }\end{array}$ \\
\hline (3)機能的観点 & $\begin{array}{l}\text { 引用の機能や役割から分類 } \\
\text { する観点 }\end{array}$ \\
\hline (4)形態的観点 & $\begin{array}{l}\text { 被引用対象の形態的な側面 } \\
\text { から分類する観点 }\end{array}$ \\
\hline (5)位置的観点 & $\begin{array}{l}\text { 引用が生起している箇所の } \\
\text { 位置に基づいて分類する観 } \\
\text { 点 }\end{array}$ \\
\hline (6)社会的観点 & $\begin{array}{l}\text { 著者が引用を行う社会的な } \\
\text { 背景に基づいて分類する観 } \\
\text { 点 }\end{array}$ \\
\hline
\end{tabular}

類スキーマ，活用時に注意すべき点につい て述べる.

\section{1 意義的観点の特性}

意義的観点は評価指標の改善に有用で あり，引用の有意性により分類する観点 である。「有意性」による区分は定性的な 順序尺度としてスキーマを構成すること ができる，著者にとって全く不要な引用と いうのは極めて少数である[11]一方， $60 \%$ 以上の著者が引用元文献中の不可欠な引 用は20-80\%であると回答している[43]た め，不可欠な引用ばかりではないと仮定す る. Hanneyら[44]の調查では,「周辺的一 限定的一重要一不可欠」4段階に引用を分 けた場合はそれぞれ35\%，56\%，8\%，1\%で あり，不可欠なほどの引用はあまり多くな いと考えられる。しかし, Hanneyらは「重 要」と「限定的」を「中心的議論として扱 われているか」で分けており，その判断は 文章の読解力や主題への精通といった専 門的な経験に左右されやすく，判断基準が 主観的になりやすい。評価を行うための観 
点としては「おざなりに行われた引用を除 く」事がまず重要であるため, 複雑化はさ せず「論文の執筆には有用だが研究そのも のには必要ない - 研究の基盤や前提とな つており必要不可欠」のように単純で瓦い に排他的に構成するのが望ましい。ただし， 低被引用論文が引用された場合より, 高被 引用論文が引用された場合の方が有意と 扱われる傾向もある[45]ため，分析対象に よるバイアスには注意が必要である.

\section{2 評価的観点の特性}

評価的観点は研究評価指標の改善に有 用であり, 被引用文献に対する引用元文献 の評価により分類する観点である. 被引用 文献に対する評価を直接的に表現してい る「賛否」を分類する場合は「賛成・肯定 一 反対・否定」のように対極的な名義尺度 として扱うことも可能だが，「肯定的一否 定的一客観的／抽象的（肯定的- 否定的の どちらでもない，判定できない等）」に分 けた場合「客観的／抽象的」の割合が70\% 以上ある[46]など，肯定的・否定的だけで は捉えきれない引用が大きな比率を占め る. そのため, 「賛成・肯定 - 中立 - 反対 ・ 否定」のような3段階の順序尺度として活 用する方が適切と考えられる. 否定の場合 は, 先行研究の完全否定ではなく主に部分 否定であり [16], 反対・否定より賛成・肯 定に該当する引用が圧倒的に多く見られ ることから「賛成・肯定」は「被引用対象 を研究の前提として用いるなど明確に肯 定的スタンスが読み取れる」，「反対・否 定」は「先行研究の部分否定や不足・弱点 の指摘を行った」，「中立」は「そのどち らでもない」のように定義するべきである.
本研究ではあくまで「引用」を分類す ることを目的としている，そのため「被 引用文献についての評価」は異なる問題 として考えなければならない. 例えば, 1 つの被引用文献に対してある文脈では不 十分であることを指摘した引用を行いな がら，別の文脈では肯定することも考え られる。被引用文献に対する評価を行う のであれば，複数個所に存在する引用を 全て含め，量的に賛成・肯定と反対・否 定の回数から総合評価を行うか，手法は 肯定しているが結果には疑問を持ってい るなど質的な評価を行う必要がある.

\section{3 機能的観点の特性}

機能的観点は主に引用索引や情報検索 のような場面で情報を付加するために有 用な観点である. そのため分類スキーマを 作成する場合には名義尺度として扱い，一 つの引用に付与する複数のラベルとして 扱うのが妥当である。従来の分類スキーマ であれば「概念的／操作的」「進歩的／並 列的」の2種類は対立的に扱われてきたが， それらと他の機能的観点で見られる区分 肢を対等に扱い，「概念や理論を参照する ため, 操作方法を参照するため, 継続性を 示す，背景情報を提供する，仮説・推測す る, 定義や前提として参照し補足・正当化 するため，比較するため，広報するため」 のように再構成した。「並列的」という区 分は「継続的ではない」という意味が強い ためスキーマには含めなかった。情報探索 上有用であれば，さらに他の区分肢を付け 加えることが望ましい，実際に区分を行う 際，引用が行われた周辺のテキストに出現 する用語を判断基準とすることで分類が 可能であるため, 文章中の動詞や構文解析 
などにより客観的に判定しやすく, 機械的 な分類も行いやすい.

概念的／操作的という区分は科学技術 分野以外に適用されることを想定してい ない[47] と指摘されるように, 研究領域に よって記述方法や内容が異なる可能性は 高い。そのため, 活用時には全てのラベル が使用されるとは限らないことに注意し なければならない。

\section{4 形態的観点の特性}

形態的観点は引用行動の傾向を掴むこ とで図書館のコレクション管理に役立て ることが可能な観点である.

被引用対象には「文献タイプ」と「デー タタイプ」がある。文献は「書籍, 原著論 文，レビュ一論文，レター論文，会議録， 見解，コメント・意見，書評，エディトリ アル，エッセイ」などのタイプからなる名 義尺度として分類が可能である。一つの引 用が複数の区分肢に当てはまることは考 えにくく，客観的に判断しや寸い，データ の引用については発展の途上であり, 未だ データの標準的なタイプは定まっていな い。あくまで例ではあるが， Nature Publishing Groupが創刊したデータジャー ナルのScientific Data誌では「オミックス， 摂動スクリーニング，体系的顕微鏡データ， 生態データ・環境データ, 行動データ, 人 ロデータ」といったタイプが挙げられてい る. 自然科学分野の実験データだけでなく, 行動データや人口データなどの社会科学 分野で活用されやすいタイプも存在する ことから，本研究ではひとまずこれらのタ イプを採用する。

${ }^{3} \mathrm{http} / / /$ www.natureasia.com/ja-jp/scientificda ta/for-authors
被引用対象の形態に関する情報は, 引用 元文献におけるレファレンス部分の記述 方式から判定可能である。しかし，データ セットの場合，Dataverse，Dryadなどのデ ータリポジトリでは引用の推奨記述形式 が存在するものの，2016年3月現在，デー タセットの引用形式が示されているスタ

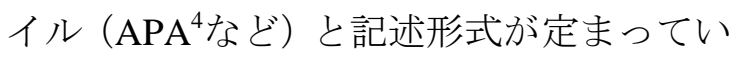
ないスタイル（MLAやChicagoスタイル） が混在しており，レファレンスの記述形式 だけでは判断しにくい環境であると言え る.

また，活用に際しては分野の慣習や雑誌 の投稿規程によって文献タイプの定義や 表記が異なるため, 分類後のデータを集 計・活用する際には調査対象に合わせた区 分の設定が必要となる.

\section{5 位置的観点の特性}

位置的観点は他の観点と掛け合わせて 引用の性質を調べるためや, 引用元文献内 の位置関係から被引用文献の類似度を評 価するためなどに活用される。構造を捉え るための単位としては「章, 節, 段落, 文, 列挙」といった単位が存在した。章の単位 は，学術雑誌のXML記述仕様であるJournal Article Tag Suite (JATS) 5で，〈sec>タグを 使用して本文のセクションを構造化する 場合, intro, methods, materials, results, discussion, conclusions, cases, subjects, supplementary-materialなどの值を記述する ことが推奨されているように，「序論，方 法, 結果, 考察, 結論, 事例, 材料」など と分けることができる，一見すると客観的

${ }^{4} \mathrm{http} / / /$ blog.apastyle.org/apastyle/2013/12/ho w-to-cite-a-data-set-in-apa-style.html

${ }^{5}$ http://dtd.nlm.nih.gov/ 
ではあるが, 文献の構造は分野の慣習や雑 誌の投稿規程，文献タイプ，著者個人の考 え方などに左右される. 例えば医学分野で はほぼIMRaD構造であるとされている[48] が，他分野では必ずしもそのような慣習は 存在しない. また,「研究方法, 研究手法, 分析手法と対象」のように表記や範囲の摇 れも多く見られるため, 統計的な分析を行 うためのカテゴリとして使用する際には， あらかじめ調查対象でどのような区分が 行われているか明らかにしてから活用す ることが望ましい。

活用時のバイアスとして, 他分野の文献 はintroductionやfindingsの箇所で行われや すく同分野の文献はそれに加え Methodologyでもよく引用されることや [49], 高被引用文献は引用元文献の前方で 引用されやすい[40]といった点にも注意す る必要がある。

\section{6 社会的観点の特性}

社会的観点は科学社会学的, 行動科学 的な分析を行う際に有用であり,「人的つ ながりによる引用，慣習による引用」が 存在する．社会的観点は研究コミュニテ イとの関わり方を観察する観点である. そのため引用元文献のみだけではなく， コミュニティや他の研究との関係から考 えなければならない。

「人的つながりによる引用」は著者の つながりに着目するため, 引用元文献お よび被引用文献の著者情報から分類され る. 近年では 1 論文あたりの著者数が増 加しているため ${ }^{6}$ 共著論文同士でも取り 扱うことができるような区分肢としなけ

${ }^{6}$ https://jipsti.jst.go.jp/foresight/dataranking/col laboration/authors/
ればならない.同時に分類として排他的 な区分とするため「自己引用-隠れ自己引 用-他者引用」からなる名義尺度として扱 う。引用元文献の第一著者が被引用文献 の著者の一人である場合を「自己引用」, 引用元文献の共著者（第一著者以外の著 者）が被引用文献の第一著者または共著 者になっている引用を「隠れ自己引用」 [50], 引用元文献と被引用文献の著者に 重なりがない場合を「他者引用」と捉え る。あくまで社会的観点におけるつなが り方の種類を定義しているだけであり， 「研究評価指標へ自己引用を含めるべき か」といった評価的側面は考慮しない. 分類を活用する場合には，被引用回数が 少ない論文ほど自己引用の割合が高い傾 向がある[51]，隠れ自己引用は近年増加 傾向にある [52]などのバイアスを意識 する必要がある。

「慣習による引用」は，従来，評価的 な意味での「おざなり」な引用を含む概 念として扱われてきた。しかし，本研究 では慣習的に行われる引用は社会的な意 味があるとの立場をとる。「慣習的な引 用」は，「先駆者への敬意」や「他の著者 も引用していた」など，コミュニティ内 の研究者が同じ文献を引用していること により引用が生起する. そのため, 引用 元文献と同じ研究領域の論文を集め，同 じ被引用文献があれば，それは慣習とし て行われた引用であるとみなすことがで きる.「同じ研究領域の論文で既に引用さ れた-同じ研究領域の論文では引用され ていない」に分けるのが妥当である。た だし，対象となる引用元文献の分野が非 常に先進的で同じ研究領域の論文が見当 たらない場合，この判定方法は適さない 
ことには注意が必要である。

\section{5 再定義の効果}

本研究では, 従来の研究で行われた引 用分類の観点を整理・再定義したうえで, それぞれの特性について述べた，分類の 観点を，(1)意義的観点，(2)評価的観点， (3)機能的観点, (4)形態的観点, (5)位置的 観点，(6)社会的観点の6つにわけ活用目 的に合わせた概念的な分類スキーマを再 構築した．意義的観点は「論文の執筆に は有用だが研究そのものには必要ない 研究の基盤や前提となっており必要不可 欠」，価值的観点は「賛成・肯定 - 中立 一反対・否定」，機能的観点は「概念や 理論を参照するため，操作方法を参照す るため, 継続性を示す, 背景情報を提供 する，仮説・推測する，定義や前提とし て参照し補足・正当化するため, 比較す るため，広報するため」，形態的観点は 「文献タイプ: 書籍, 原著論文, レビュ 一論文，レター論文，会議録，見解，コ メント・意見, 書評, エディトリアル, エッセイ」「データ：オミックス，摂動 スクリーニング，体系的顕微鏡データ， 生態データ・環境データ, 行動データ, 人口データ」, 位置的観点は「章 (序論, 方法, 結果, 考察, 結論, 事例, 材料), 節，段落，文，列挙」，社会的観点は「人 的つながり：自己引用-隠れ自己引用-他 者引用」「慣習：同じ研究領域の論文で 既に引用された-同じ研究領域の論文で は引用されていない」のように分けた。 調查対象とする文献の研究分野や論文夕 イプなどによって, どの観点が特に重視 されるかといった違いはあるだろう。し
かしながら，引用という現象を統合的に 整理し，分野に依存せず適用できる分類 スキーマを設定したことは，分野間比較 を可能にする共通基盤の構築につながる ものと考える.

次に，従来の区分肢を統合できたこと と分離できたことが効果として挙げられ る。例えば Garzone と Mercer[8]が実験で 用いたカテゴリでは「肯定的タイプ」と 「否定的タイプ」は単純に異なる区分肢 として扱われていた。しかし，本研究で は評価的観点である「賛否」という観点 で見られる区分肢としてそれぞれを扱い， 実証的な先行研究の研究結果から「中立」 という区分肢もまた現実的には必要であ ることを明らかにした．引用理由を分析 することや機械的な分類可能性を模索す るために実際的な区分を用いるだけでは 得られない，整理による効果であったと 言える。 また，本研究では研究評価指標 で「おざなり」とされて不要とされやす い「慣習的に行われる引用」を明確に評 価的観点と社会的観点として概念的に異 なる観点から生成される区分として分離 したことで，引用が分類される観点に応 じて必要とされる区分のあり方も議論で きる準備が整ったと言える.

\section{6 おわりに}

本研究では引用を分類する際に用いる 観点を体系的に整理・再定義し, 各観点 の特性と分類スキーマについて述べた. 引用を分類する場合に用いられる観点を 整理することで，複合的な観点から用い られていた区分肢を分離することができ た。実際に引用分類スキーマを用いて分 
類作業を行う場合には，作業者の判断に ブレがでない客観的な判定基準や引用部 分の機械的な検出方法も検討し, その精 度や問題点を検証する必要がある.また， 今回は引用を分類する際の観点を整理し たため「引用」単位で分類することを前 提に考察しているが, 特に研究評価指標 へ適用するために計量する際は 1 つの被 引用文献が引用元文献内で何度も引用さ れる場合を考慮する必要がある，今後の 研究では, 今回整理した引用分類の観点 に対しどのように区分肢を設定し，被引 用文献の重みづけの方法を構築するか検 討していく必要がある.

\section{謝辞}

本研究に際して種々ご指導を頂きまし た筑波大学の小野寺夏生名誉教授, 緑川信 之教授に深謝致します。 また日常の議論を 通じて多くのアドバイスをいただいた筑 波大学大学院の学生の皆様に感謝致しま す.

\section{参考文献}

[1] Shotton, David: "CiTO, the Citation Ty ping Ontology" , Journal of Biomedical Se mantics, vol.1(Suppl .1):S6, pp.1-18, 2010.

[2] Small, Henry:" Citation context analysis", Dervin, B. J. \& Voigt, M. J. (eds.), Progress in Communication Sciences,3, Norwood, NJ: Ablex, pp. 287-310, 1982.

[3] Peritz, Buma C.: "A classification of citation roles for the social sciences and related fields", Scientometrics, Vol.5, pp.303-312, 1983.
[4] Garfield, E. "Can citation indexing be automated?" In: Essays of an Information Scientist, Vol.1, pp. 84-90 Philadelphia, PA: ISI Press; 1977

[5] Lipetz, ben-ami: "Improvement of the selectivity of citation indexes to science literature through inclusion of citation relationship indicators", American Documentation, Vol.16, pp.81-90, 1965.

[6] Moravcsik, Michael J.; Murugesan, Poovanalingan: "Some results on the function and quality of citations", Social Stuies of Science, Vol.5, No.1, pp.86-92, 1975.

[7] Brooks, Terence A.: "Private acts and public objects: an investigation of citer motivations", Journal of the American Society for Information Science, Vol.36, pp.223-229, 1985.

[8] Garzone, Mark ; Mercer, Robert E.: "Towards an Automated Citation Classifier", Advances in Artificial Intelligence 2000, Hamilton, H. and Yang, Q. (Eds.), Montréal, Québec, Canada, Springer, pp.337-346, 2000.

[9] White, Howard D.: "Citation analysis and discourse analysis revisited", Applied linguistics, vol.25, iss.4, pp.89-116, 2004.

[10] Cano, V.: "Citation behavior: Classification, Utility, and location", Journal of the American Society for Information Science, Vol.40, pp.284-290, 1989.

[11] Vinkler, P.: “A quasi-quantitative citation model”, Scientometrics, Vol.12, pp.47-72, 1987.

[12] Small, Henry: "On the shoulders of Robert Merton: Towards a normative theory of citation", Scientometrics, Vol.60, No.1, pp.71-79, 2004. 
[13] Harwood, Nigel : "An interview-based study of the functions of citations in academic writing across two disciplines". Journal of Pragmatics, vol.41, pp.497-518. 2009.

[14] Bornmann, Lutz; Daniel, Hans - Dieter : "What do citation counts measure? A review of studies on citing behavior" Journal of Documentation, vol.64, Iss.1 , pp.45-80, 2008. [15] Ding, Ying; Zhang, Guo ; Chambers, Tamy ; Song, Min. ; Wang, Xiaolong ; Zhai, Chengxiang: "Content-based citation analysis: The next generation of citation analysis", Journal of the Association for Information Science and Technology, vol.65, Iss.9, pp.1820-1833, 2014.

[16] Chubin, Daryl E.; Moitra, S. D.: “Content analysis of references: Adjunct or alternative to citation counting?", Social Studies of Science, Vol.5, No.4, pp.423-441, 1975.

[17] Murugesan, Poovanalingam; Moravcsik, Michael J.: "Variation of the nature of citation measures with journals and scientific specialties", Journal of the American Society for Information Science, Vol.29, Iss.3, pp.141-147, 1978.

[18] Spiegel-Rösing, Ina: "Bibliometric and content analysis", Social Studies of Science, Vol.7, No.1, pp.97-113, 1977.

[19] Oppenheim, Charles; Renn, Susan P: "Highly cited papers and the reasons why continue to be cited", Journal of the American Society for Information Science, Vol.29, pp.225-231, 1978.

[20]Frost, Carolyn O.: "The literature of online public access catalogs, 1980-1985 : an analysis of citation patterns", Library Resources and Technical Services, vol.33, No.4, pp.344-357,
1989.

[21] McCain, Katherine W.; Turner, Kathleen: "Citation context analysis and aging patterns of journal articles in molecular genetics", Scientometrics, vol.17, Iss.1, pp.127-163, 1989.

[22] Brooks, Terence A.: "Evidence of complex citer motivations", Journal of the American Society for Information Science, Vol.37, pp.34-36, 1986.

[23] Line, Maurice B.; Sandison, A.: "PROGRESS IN DOCUMENTATION: 'obsolescence' and changes in the use of literature with time", Journal of Documentation, Vol. 30, Iss.3, pp.283-350, 1974.

[24] Gilbert, G. Nigel: "Referencing as persuation", Social Studies of Science, vol.7, No.1, pp.113-122, 1977.

[25] Bavelas, Janet B.:“The social psychology of citations", Canadian Psychological Review, vol.19,Iss.2, pp.158-163, 1978.

[26] Cole, Stephen The growth of scientific knowledge: Theories of deviance as a case study. In The Idea of Social Structure; Papers in Honor of Robert K. Merton, pages. 175-220. New York: Harcourt, Brace Jovanovich., 1975. [27] Duncan, E. B.; Anderson, F.D.; McAleese, R.: Qualified citation indexing: its relevance to educational technology. In Information retrieval in educational technology: proceedings of the first symposium on information retrieval in educational technology., pp70-79. Aberdeen: University of Aberdeen., 1981.

[28] Finney, B. "The reference characteristics of scientific texts" Master's thesis, The City 
University of London., 1979.

[29] Small, Henry G. "Cited documents as concept symbols". Social Studies of Science, vol.8, No.3, pp.327-340, 1978.

[30] Weinstock, Melvin: Citation indexes. In Encyclopedia of Library and Information Science, vol.5, Dekker, New York, 1971.

[31] Garzone, Mark. : "Automated classification of citation using linguistic semantic grammars". Master's. thesis, Dept. of Computer Science, The University of Western Ontario, 1996.

[32] Teufel, Simone; Siddharthan ,Advaith; Tidhar, Dan: "Automatic Classification of citation function" Proceedings of the 2006 Conference on Empirical Methods in Natural Language Processing(EMNLP 2006), 2006, Sydney, Australia, Association for Computational Linguistics, pp.103-110, 2006. [33] Chang, Yu-Wei: "A comparison of citation contexts between natural sciences and social sciences and humanities", Scientometrics, Vol.96, No.2, pp.535-553, 2013.

[34] Case, Donald O., Higgins, Georgeann M.: "How can we investigate citation behavior? A study of reasons for citing literature in communication", Journal of the American Society for Information Science, Vol.51, pp.635-645, 2000.

[35] Bonzi, Susan; Synder, H.W.: "Motivations for citation: a comparison of self citation and citation to others", Scientometrics, Vol.21, pp.245-254, 1991.

[36] Shadish, William R.; Tolliver, Donna; Gray, Maria; Sen Gupta, Sunil K.: "Author Judgements about Works They Cite: Three
Studies from Psychology Journals", Social Studies of Science, Vol. 25, no. 3, pp.477-498, 1995.

[37] Willett, Peter: "Readers' perceptions of authors' citation behavior", Journal of Documentation, Vol.69, No.1, pp.145-156, 2013.

[38]Voos, H.; Dagaev, K. S.: "Are all citations equal? Or. Did we Op. Cit. Your Idem?", Journal of Academic Librarianship, Vol.1, pp.19-21, 1976.

[39]Bertin, Marc ; Atanassova, Iana; Gingras, Yves; Larivière, Vincent: "The invariant distribution of references in scientific articles“, Journal of the Association for Information Science and Technology, Vol.67, Iss.1, pp.164-177, 2016.

[40] Hu, Zhigang; Chen, Chaomei; Liu, Zeyuan:"Where are citations located in the body of scientific articles? A study of the distributions of citation locations", Journal of Informetrics, Vol.7, Iss4, pp.887-896, 2013.

[41] Callahan, Alison; Hockema, Stephen ; Eysenbach, Gunther: "Contextual cocitation: Augmenting cocitation analysis and its applications", Journal of the American Society for Information Science and Technology, Vol.61, No.6, pp.1130-1143, 2010.

[42]江藤正己.「「用論文における引用箇 所間の近さをとらえる尺度」, 第15回(2007 年度) 研究報告会論文集, 情報知識学会誌, Vol. 17, No. 2, pp. 65-68, 2007.

[43] Liu, Mengxiong: "A study of citing motivation of Chinese scientists". Journal of Information Science, Vol.19, No.1, pp.13-23, 1993.

[44] Hanney, Steve; Frame, Iain; Grant, 
Jonathan; Buxton, Martin; Young, Tracey ; Lewison, Grant: "Using categorisations of citations when assessing the outcomes from health research", Scientometrics, Vol.65, Iss.3, pp.357-379, 2005.

[45]Hooten, Patricia A.: "Frequency and functional use of cited documents in information science", Journal of the American Society for Information Science, Vol.42, Iss.6, pp.397-404, 1991.

[46] Athar, Awais ; Teufel, Simone: "Context-enhanced citation sentiment detection", Proceedings of the 2012 Conference of the North American Chapter of the Association for Computational Linguistics: Human Language Technologies (NAACL HLT '12), pp.597-601, 2012.

[47] Swales, John : "Research articles in English", Genre Analysis: English in Academic and Research Settings, Cambridge, UK, Cambridge University Press, pp.110-176, 1990.

[48]青木仕：「医学における情報ソースと
してのStructured Abstracts（構造化抄録） の研究」, 総ページ数p. 65，2005. 博士論 文.

[49] Halevi, Gail; Moed, Henk F. : "The thematic and conceptual flow of disciplinary research: a citation context analysis of the journal of informetrics", Journal of the American society for information science and technology, Vol.64, No.9, pp.1903-1913, 2013.

[50] Zmaić, Ljerka; Maričić ,Siniša; Simeon, Vladimir: "Visibility of peripheral journals through the science citation index", Information Processing \& Management, Vol. 25, Iss.6, pp.713-719, 1989.

[51] Aksnes, Dag W.:"A macro study of self-citation", Scientometrics, Vol.56, no.2, pp.235-246, 2003.

[52] Costas, Rodrigo; van Leeuwen,Thed N.; Bordons, Maria : "Self-citations at the meso and individual levels: effects of different calculation methods", Scientometrics, vol.82, no.3, pp.517-537, 2010.

(2016年6月28日受付) (2016年9月18日採択) 
付表 1 調査対象文献一覧

\begin{tabular}{|c|c|c|c|}
\hline 著者 & 研究目的 & 調査手法 & 対象分野 \\
\hline Garfield, 1962 & 引用理由の解明 & - & - \\
\hline Lipetz, 1965 & 引引用索引の改善のため & $\begin{array}{l}\text { 対象論文を読みス } \\
\text { キーマ構築 }\end{array}$ & 物理学 \\
\hline $\begin{array}{l}\text { Murugesan and } \\
\text { Moravcsik, } 1975\end{array}$ & $\begin{array}{l}\text { 文脈における引用の質 } \\
\text { の測定 }\end{array}$ & 文脈分析 & 物理学 \\
\hline $\begin{array}{l}\text { Chubin and Moitra, } \\
1975\end{array}$ & $\begin{array}{l}\text { 引用する文献の採用理 } \\
\text { 由の解明 }\end{array}$ & インタビュー & 物理学 \\
\hline Voos and Dagaev, 1976 & $\begin{array}{l}\text { 引用分析を行う際に位 } \\
\text { 置を考慮する必要性の } \\
\text { 明示 }\end{array}$ & $\begin{array}{l}\text { 被引用文献が掲載 } \\
\text { された位置を集計 }\end{array}$ & $\begin{array}{l}\text { 主に生物学、医学、物理学 } \\
\text { (上記分野の文献を引用し } \\
\text { た文献が対象) }\end{array}$ \\
\hline $\begin{array}{l}\text { Ina Spiegel-Rusing, } \\
1977\end{array}$ & $\begin{array}{l}\text { 学際的な雑誌の傾向の } \\
\text { 解明 }\end{array}$ & 内容分析 & 科学社会学 \\
\hline $\begin{array}{l}\text { Oppenheim and Renn, } \\
1978\end{array}$ & $\begin{array}{l}\text { 古い文献が引用される } \\
\text { 理由の解明 }\end{array}$ & 文脈分析 & $\begin{array}{l}\text { 主に物理学と物理化学 } \\
\text { (※物理学と物理化学の論 } \\
\text { 文を引用した文献が対象) }\end{array}$ \\
\hline Cano, 1989 & $\begin{array}{l}\text { 引用のタイプ, 重要性, } \\
\text { 位置の関倸の解明 }\end{array}$ & アンケート & 工学 \\
\hline Peritz, 1983 & $\begin{array}{l}\text { 引用の役割を実証的に } \\
\text { 分類するためのスキー } \\
\text { マの提案 }\end{array}$ & 内容分析 & 社会科学関連領域 \\
\hline Brooks, 1986 & $\begin{array}{l}\text { 引用分類の評価として } \\
\text { の有用性の検証, 区分肢 } \\
\text { 同士の相関の解明 }\end{array}$ & インタビュー & $\begin{array}{l}\text { 解剖学, 人類学など } 15 \text { 分 } \\
\text { 野 }\end{array}$ \\
\hline Vinkler, 1987 & 引用理由の解明 & $\begin{array}{l}\text { アンケート（複数 } \\
\text { 回答可） }\end{array}$ & 化学関連領域 \\
\hline Bonzi and Snyder, 1991 & $\begin{array}{l}\text { 自己引用と他者引用の } \\
\text { 違いの解明 }\end{array}$ & アンケート & $\begin{array}{l}\text { 化学, 生物学, 地学, 物理 } \\
\text { 学 }\end{array}$ \\
\hline Shadish et al., 1991 & $\begin{array}{l}\text { 著者が引用を行う判断 } \\
\text { 基準の解明 }\end{array}$ & アンケート & 心理学 \\
\hline $\begin{array}{l}\text { Case and Higgins, } \\
2000\end{array}$ & 引用動機の解明 & アンケート & 人文社会系 \\
\hline $\begin{array}{l}\text { Garzone and Mercer, } \\
2000\end{array}$ & $\begin{array}{l}\text { 引用機能の分類の自動 } \\
\text { 付与 }\end{array}$ & 自動分類 & 生化学, 物理学 \\
\hline Hanney et al., 2005 & $\begin{array}{l}\text { リサーチインパクトの } \\
\text { 評価 }\end{array}$ & 文脈分析 & 糖尿病 \\
\hline Teufe1, 2006 & 自動引用索引の改善 & 自動分類 & コンピュータ科学 \\
\hline Harwood, 2009 & $\begin{array}{l}\text { 引用行動や記述方式の } \\
\text { 比較 }\end{array}$ & インタビュー & $\begin{array}{l}\text { コンピュータ科学, 社会科 } \\
\text { 学 }\end{array}$ \\
\hline Chang, 2013 & 引用機能の分野間比較 & 自動分類 & 自然科学, 社会科学 \\
\hline $\begin{array}{l}\text { Hu Z, Chen C, Liu Z. , } \\
2013\end{array}$ & $\begin{array}{l}\text { 引用の位置と分布の関 } \\
\text { 係の }\end{array}$ & 自動分類 & 計量情報学 \\
\hline
\end{tabular}

